\title{
The Application Of Field Trip Methods To Improve The Ability To Write Poetry On Students Of Smp Grade Vii Using Chairil Anwar's "Senja Di Pelabuhan Kecil"
}

\author{
${ }^{1 s t}$ Mawaddah Warohmah Azhari \\ Applied Linguistics \\ Departement Of Graduated School \\ Yogyakarta State University \\ J1. Colombo. No.1 Yogyakarta 55281, Indonesia \\ mawaddah0698pasca2016@student.uny.ac.id
}

Abstract- This Paper aims to emphasize the application of the field trip method, especially in improving the ability to write poems "Senja Di Pelabuhan Kecil" by Chairil Anwar which is used as a medium for literary learning conducted in the classroom. Writing skills are one of the language skills gained from the practice and practice process to produce creative writing that is needed in accordance with personal learning styles or learning in a natural way. The use of the right method can improve student's ability in writing so that the method of teaching teachers must use creative learning techniques that vary. The teacher must be able to make various solutions in writing learning, one of which is the use of the field trip method used by students to have a learning experience that is an integral part of the school curriculum. Field trips as teaching ang learning methods can be used by students to visit certain places so can improve learning to write poetry by bringing learning objects closer to facilitate students in pouring ideas into writing. Keywords-Writing skills, Field Trips, Poetry Senja di Pelabuhan
Kecil

\section{INTRODUCTION}

Language skills are things that are taught in the process of language learning. Language learning is conducted in ordet to-someone is able to speak well and correctly according to the situation and conditions where person live Indonesian language as a teaching material is viewed in terms of language skills which has four important components and one of the components is writing skills. Writing is an activity of pouring ideas, devoting the contents of the heart that is implemented into a work in the form of writing. Sukirno (2010:3) argues that creative writing is the activity of pouring ideas in writing way or producing creative power based on thoughts and feelings in writing form. An example of creative writing activity is writing poetry. The use of the

\author{
${ }^{2 n d}$ Prof. Haryadi, M.Pd \\ Applied Linguistics \\ Departement Of Graduated School \\ Yogyakarta State University \\ J1. Colombo. No.1 Yogyakarta 55281, Indonesia \\ Prof_haryadi@yahoo.co.id
}

right method can improve students' ability in writing. It is very necessary and the method of teaching must use learning techniques that creatively vary. Regarding to the problems that are widely seen, so the teacher must be able to make various solutions in writing learning. In this case, one of them is the use of the field trip method used by students as a cruise to have a specific learning experience. Field trip method is also an integral part of the school curriculum. The use of field trips as a teaching and learning method for students under the guidance of teachers in visiting certain places with a view to learning can improve learning to write poetry because it can bring learning objects closer to students so that it makes it easier for students to express their ideas in writing.

Improving the ability to write poetry with the field trip method is conducted based on the reason that the condition of students in receiving writing material is not in line with expectations because the teaching and learning methods used by the teacher with the lecture method and the media examples have not overcome changes in the students' work in writing.

Essentially language learning or language skills teaching aims to foster and develop student language skills. Skilled in language means being skilled at listening, speaking, reading, and skilled in writing in good and right Indonesian. Language skills have several characteristics. First, language 
skills are mechanistic. Second, language experience. Third, the type of application questions is very suitable in developing language skills. Writing skills are never separated from the three characteristics found in the writing skills above which have important and meaningful role. From the four existing language skills, writing skills are a language skill that takes the longest time because the process carried out by someone in language learning always starts with the sequence of listening, speaking, reading, and writing as well as a proverb in English, " The last but not the least.

In terms of learning activities which is conducted in Junior High School (SMP) the ability to write poetry is one part of literary skills that must be taught and mastered by students because writing poetry can be used as a way of shaping character, sportivity, and can foster student sensitivity to the surrounding environment. Semi (1993:194) says that the purpose of teaching literature is to make students having a sense of sensitivity to literary and environmental work, so that they feel compelled and interested to read it, from the reading of a literary work students have a good understanding of humanity and humanity about values and get ideas new. With the ability to recognize values in life, students are expected to be able to express their understanding of their personal experiences in the form of writing poetry.

The teacher is too much focused on the textbook as a learning resource in providing material and examples of poetry that are already in the textbook. Learning tends to be theoretically informative rather than productive appreciative, which causes students not to be creative and not to have freedom to express their feelings and the most prominent impact is that students are not interested in writing poetry because they consider it very difficult at first. Students have difficulty expressing their thoughts and feelings in the form of poetry such as difficulty in finding ideas, finding the first words in his poetry, difficulty in developing ideas because of the lack of mastery of words, difficulty in detailing objects written in his poetry, difficulty limiting topics from the theme given by teachers, difficulty in sorting details detail about the object he wrote in poetry, and not used to pouring his thoughts and feelings in the form of poetry. Therefore, students need a long time to express ideas in the form of poetry, moreover to be able to express an object in poetic words. Establishing the use of the field trip method with the learning method used by the teacher in utilizing a location that provides a real context will more stimulate students to write poetry and will facilitate students in expressing their thoughts, feelings, and imagination into poetry.

\section{DISCUSSION}

\section{A. The Nature of Poetry Writing Ability}

Writing is one of four aspects of skills that form an indirect communication that uses written media. Nurgiyantoro (2009:296) stated that "Writing activity is a form of manifestation of the latest language ability and skills that which are mastered by language learners after the ability to listen, speak, and read. Writing ability is a complex ability. Suwandi (2005) suggests a number of components that must be faced by a person when writing poetry is an understanding of the purpose of writing, an understanding of the prospective readers, understanding of the content (between relevance, clarity, originality, and logic), understanding of the writing process, understanding the choice of words, understanding of aspects of organizing,understanding of grammatical,and understanding of writing techniques. Nurgiyantoro (2009:306) suggests such elements that need to be assessed in an essay are: (a) Content; (b) Form; (c) Grammar; (d) Style; and (e) Mechanics.

In essence, the poem has a broad and varied meaning so that the poet has the right to make their own definitions of poetry whether the definition is explicitly stated or not. Pradopo (2009:7)"The poem expresses thoughts that instill feelings that stimulate the sense of the senses in a rhythmic arrangement." All of them are important things that are recorded, expressed, and expressed in an interesting and suggestive way so that it can be said that a poem can awakened from physical structure and inner structure. 


\section{Elements That Build Poetry}

Tarigan (1984:9) reveals that a poem contains an overall meaning which is a combination of the poet's theme; his feelings; the tone; and mandate. Semi (1993:107) divides the anatomy of poetry on two parts: physical form and mental form. Both forms are intertwined and combined in a way that allows a poem to reflect the meaning of the beauty and imagination of the reader. The physical and mental form of a poem is a totality consisting of three layers, namely: (a) Sound layer; (b) Layer of meaning; (c) Theme layer.

Poetry as a work of art is poetic. A poem that does not have artistic value will not be poetic and poetry that is not poetic cannot be called poetry. The poetic word already contains a value of beauty that is special for poetry. A poem is poetic when it can evoke feelings of attracting attention, giving rise to clear responses, and generally generating renewal. Poetry can be achieved in a variety of ways, for example with visual forms: typography, arrangement of temples; with sound: piracy, assonance, alliteration, figurative sound, symbol of taste, and orchestration; with word selection (diction); figurative language; means of rhetoric; grammatical elements; language style; and so on (Pradopo, 2009:13).

\section{The Nature of Writing Poetry}

Waluyo (2001:2) says "Poetry is co-extensive with life". This means that the poem stands side by side in the same position as life. The language of poetry is more solid, more beautiful, more brilliant, and more lively than prose language or the language of everyday conversation. It contains the use of symbols, metaphors and intuitive forms to express ideas, feelings, and emotions. The poetic language density is actually very closely synchronous and integrative with the poet in an effort to compress a number of thoughts, feelings, emotions, and life experiences he expresses. Poets can express very broad things in a compact and concise form. The process of creating poetry can be explained as follows: (1) Poetry consists of material content and form material;(2) Content in poetry consists of ideas, feelings, and emotions;(3) Form material in poetry in the form of vocabulary and structure;(4)
Poetry material consisting of ideas, feelings, and emotions can be extracted from experiences or events of daily life and natural events.

Poetry is unique in its creative process. The existence of poetry's peculiarities often makes students feel difficult to produce a work (poetry). This is also caused by poetry that has abstract properties because the creative process takes place in the world of poet's imagination. However, the abstract nature must be realized in the form of real language, bound to linguistic rules. Writing activity is a process of transferring thoughts or feelings in symbols of literary forms that others can enjoy that can take place in learning to write poetry.

Waluyo (2005:45) there are four levels of appreciation such as the level of loving, the level of enjoyment, the level of reaction, and the productive level. Writing poetry is the part that is at the last level of appreciation in appreciating literary works. Thus, the activity of writing poetry is the last level of appreciation because at this stage the appreciation process is not only stalled in the process of enjoying literary works, but further in the last stage a person's appreciation process is required to be able to produce a work (poetry). The implementation of students' poetry writing activities can freely incorporate their inner experience in the world of imagination which is realized in the form of graphic symbols in the form of word choice (diction) that correspond to typography, poetry, rhythm and other poetic sound elements that support each other. Sayuti (2002:25) poetry prioritizes things that are intuitive, imaginative, and synthesized. Therefore, in the process of its creation, concentration and intensification of various matters related to personal expression are the main concerns. Based on the nature of the poetry makes poetry as a literary genre which is seen from the language to be the most concentrated and solid. Each phrase, word, even sound and row arrangement has an absolute importance for the expression of the poet's experience.

\section{B. Field Trip Learning Methods}

In the teaching and learning process the teacher must have a strategy in order to the students can learn effectively and efficiently and reach the 
expected goals. One step to have a strategy is mastering presentation techniques or usually called teaching methods. Maolani (2007:1) states "The method literally means the way." In general usage, the method is defined as a way of carrying out an activity or way of doing work using facts and concepts systematically. The method is more procedural and systemic because the goal is to facilitate the work of a job. Thus, the learning method means a method that contains standard procedures for carrying out educational activities, especially the activities of presenting subject matter to students. Learning methods have three positions,: (1) Extrinsic motivation as a motivational learning tool; (2) Methods as teaching strategies in dealing with individual differences in students; (3) The method as a tool to achieve goals and methods can increase the absorption of material for students so that it has a direct impact on achieving goals. Each method has certain characteristics with all their strengths and weaknesses. "A method may be good for a particular purpose, subject matter or certain situations and conditions, but not appropriate for other situations. A method that is considered good for a particular subject is sometimes not successful if it is used by other teachers.

Field Trip is not just a recreation but learning or deepening a lesson by seeing the reality. The Field Trip method is carried out by inviting students to study outside the classroom with a teacher's guide through written instructions and assignments of activities. There are clear instructions and tasks from the teacher so that activities carried out outside the classroom can run in accordance with the objectives and learning plans.

In practice, the field trip method can be used to introduce new concepts that students have not yet known and reinforce the images given in the classroom. Moreover, the field trip also emphasizes learning experiences outside the classroom that offer unique experiences for students to connect subject matter with the world around them. Field Trip requires the teacher to present a learning design that is able to generate motivation and enthusiasm for student learning in a fun presentation. Therefore, teacher creativity is very necessary in planning learning activities by applying the field trip method. The implementation of language learning is strongly influenced by the learning approach used by the teacher. The approach is very influential on determining the learning objectives, methods, techniques used.

Roestiyah (2008:85) says that field trips are not just recreation, but to learn or deepen the lesson by seeing the reality. That is why the field trip method is said to be a way of teaching that is done by inviting students to visit a certain place or object outside of school to study or investigate something like reviewing shoe factories, car repair shops, department store and others. Sagala (2006:214) said the field trip is a cruise conducted by students to complement certain learning experiences and is an integral part of the school curriculum, so that with the field trip as a teaching-learning method for students under the guidance of teachers to visit places a particular place with a view to learning such as (1) Students can observe realities that vary from close;(2) Students can experience new experiences by trying to participate in an activity; (3) Students can answer problems or questions by seeing, hearing, trying, or proving directly;(4) Students can obtain information by holding interviews or listening to lectures given on the spot; (5) Students can learn something internally and comprehensively.

The advantages of the field trip method according to Roestiyah (2008:87) include the followings: (1) Students can participate in various activities carried out by officers on tourism objects and experience and live directly what their work is; (2) Students can see various activities of officers individually or in groups and are directly observed who will deepen and broaden their experience; (3) Students on this occasion can ask questions, find the first source of information to solve all the problems faced; and (4) Students can obtain various knowledge and experiences that are integrated with the object being reviewed. The purpose of the field trip technique is (1) students are able to get direct experience of the object they see; (2) students are able to participate in one's work duties; (3) students are able to be responsible. Thus, students are able to solve the problems they face in learning. 


\section{Application of Field Trip Method Implementation on Learning to Write Senja Di Pelabuhan Kecil "Senja Di Pelabuhan Kecil" by Chairil Anwar in grade VII of Junior High School}

\section{Senja Di Pelabuhan Kecil \\ Karya Chairil Anwar}

Ini kali tidak ada yang mencari cinta

diantara gudang, rumah tua, pada cerita

tiang serta temali. Kapal, perahu tiada berlaut menghembus diri dalam mempercaya mau terpaut

Gerimis mempercepat kelam.

Ada juga kelepek elang

menyinggung muram, desir hari lari berenang menemu bujuk pangkal akanan.Tidak bergerak

dan kini tanah dan airtidur hilang ombak

Tiada lagi. Aku sendiri.Berjalan

menyisir semenanjung, masih pengap harap

sekali tiba di ujung dan sekalian selamat jalan dari pantai keempat, sedu penghabis bisa terdekap

(Chairl Anwar, 1946)

The field trip method will be very useful when applied in learning to write poetry. This method can inspire students in expression which is expressed in poetry by observing objects, for example natural objects in the form of ports (pelabuhan) and dusk (senja) like Chairil Anwar's poem entitled "Senja di Pelabuhan Kecil". In the poem written by Chairil Anwar it is described about love that can no longer be obtained. The painter depicts buildings, old houses, stories of pillars and rods, ships and boats that do not link, they all express feelings of sadness and loneliness so that the poet feels that the objects in the harbor make him feel, blowing himself into believing that he wants to stick. So, how can the shape of the port and dusk be written into poetry using poetic words. After that, students can practice it by doing it outside the classroom, where students observe objects directly by taking steps such as Preparation Steps, Implementation Steps, and Follow-up.
Application Of Field Trip Method Assessment in Learning to Write "Senja Di Pelabuhan Kecil" by Chairil Anwar in grade VII of Junior High School

Nurgiyantoro (2009:5) defines assessment as a process to find out (test) whether an activity, activity process, output of a program is in accordance with the objectives or criteria that have been determined. The importance of assessment in a learning is to: (1) compare students with other students; (2) knowing whether students meet certain standards; and (3) helping student learning activities (Suwandi, 2009:9). Assessment of both formal and informal learning outcomes is held in a pleasant atmosphere that allows students to show what they understand and what are able to do. Appropriate assessment techniques require data relating to the object of research carried out, including assessment techniques for performance and portfolios. To observe the performance of students is to use a rating scale instrument. The rating scale is an assessment that is prepared by looking for indicators that reflect the next skill determined the rating scale for each indicator (Majid, 2006:277).

Curriculum Center of the Ministry of National Education Research and Development Agency (2006:9) states that rating scale is an assessment of performance that allows the assessor to give a middle value to the mastery of certain competencies because of continuous value giving where the choice of more than two categories. The rating scale ranges from imperfect to very perfect, for example: $1=$ good enough; 2 = good; 3 = very good.

In connection with this, weighting the valuation is not absolute because every teacher can choose or make a model that is considered most appropriate (Nurgiyantoro, 2009:208). Thus in determining the weight of the teacher's assessment should pay attention to the assessment criteria used and the objectives to be achieved so that the assessment can really measure the success of learning objectives both process and results. Meanwhile, to find out the strengths and weaknesses of students' ability to write poetry, hence, portfolio assessment techniques are used. 


\section{Assessment of the Learning Process}

Students need to have a positive attitude towards ongoing learning. Sudjana (2008:56) reveals that what is achieved by students is the result of the process that is carried out through an activity program designed and implemented by the teacher in the teaching process. This means that student learning outcomes cannot be separated from the learning process they experience. In general, the object of attitudes that need to be assessed in the learning process based on the Guidelines for Class Assessment by the Baan Curriculum Center for Research and Development of the Ministry of National Education (2006:10-11) are: (1) Attitudes towards Learning Material; (2) Attitudes towards Teachers/Teachers;(3)Attitude towards the Learning Process; and (4) Attitudes relating to Values /Norms Related to Student Study Materials.

\section{Assessment of Learning Outcomes}

Sudjana (2008:3) says that the assessment of learning outcomes is the process of assigning value to learning outcomes achieved by students with certain criteria. This implies that the object being assessed is learning outcomes that are tailored to the learning objectives. Nurgiyantoro (2009:331) states that literary tests including poetry include cognitive, affective, and psychomotor tests. The tests arranged by the teacher should be adjusted to the teaching objectives of the language and literature to be achieved. A test or assessment used should be adjusted to the learning objectives so that the assessment of results in poetry learning in grade VII is based on the results of students' work in the form of poetry. The KKM that is determined is $\geq 63$, this means students are declared complete in learning if they get grades nilai 63. The things that become indicators of assessment include: originality of ideas/ content, selection of words (diction), rhyme (poetry), and figurative language. These four things are adapted to the meaning of poetry and ways to achieve the beauty of a poetry work as stated by several literary experts, such as Waluyo, Pradopo, Semi, and Sayuti. For the format of assessment of the results of writing poetry, researchers adopted the assessment format proposed by Suwandi (2009:129) as about : Tabel Penilaian Hasil Pembelajaran and Tabel Pedoman Penskoran Menulis Puisi

\section{Conclusion}

Some of the factors that support the implementation of the field trip method in the learning process of writing poems "Senja di Pelabuhan Kecil".by Chairil Anwar in grade VII students of SMP is through the Field Trip It can improve learning to write poetry because it brings learning objects closer to students will make it easier for students to pouring ideas into writing so that in improving the ability to write poetry using the field trip method can be used as a way to see the condition of students in accepting the writing material that is currently in accordance with the expectations and teaching and learning methods used by the teacher with the lecture method and the media the examples have not overcome changes in the results of the students' work in writing. Whereas the inhibiting factors in the learning process of writing poetry in class VII have so far received no positive response from students so that from the results of analysis on student poetry it is found that: (1) most of the students' poetry consists of only a few lines, an average of 3 line; (2) Does not indicate a content organization that is coherent but jumps up and down, for example the first line describes the beauty of nature, while the second line is about a flag pole; (3) themes written in poetry are not in accordance with the teacher's task, for example about the beauty of nature, but written about the outpouring of students' hearts; (4) does not describe a unified idea; (5) students' poems which are considered to lack attention to quality criteria for word selection, creativity in using rhyme, and use of figurative language.

\section{Acknowledgment}

Researchers say thank to Allah Almighty who always gives help to all the interests of researchers, thanks to all his compatriots who have helped in completing this research, thanks to my lecturer in the applied linguistics department of Yogyakarta State University, namely Prof. Haryadi, M.Pd, Prof. Pratomo Widodo, and my thesis supervisor Prof. Burhan Nurgiyantoro who has given me a lot of support and guidance. Thank you very much especially to my parents who gave a lot of enthusiasm to Mawaddah Warohmah Azhari to be 
able to study continuously until now in the Applied Linguistics program.

\section{References}

[1] Majid, Abdul. 2006. Perencanaan Pembelajaran:MengembangkanStandar Kompetensi Guru . Bandung: Rosdakarya.

[2] Andayani. 2008. Pembelajaran Apresiasi Sastra Berbasis Quantum Learning di Sekolah Dasar. Surakarta:UNS Press.

[3] Asmani,Jamal Ma'mur. 2010. Tips Menjadi Guru Inspiratif, Kreatif, dan Inovatif. Yogyakarta: DIVA Press.

[4] Anwar, Chairil. 2016. Aku Ini Binatang Jalang: Kumpulan Puisi. Jakarta : PT. Gramedia Pustaka Utama.

[5] Atar, Semi. 1993.Anatomi Sastra. Padang : Angkasa Raya.

[6] Nurgiyantoro, Burhan.2009. Penilaian dalam Pengajaran Bahasa dan Sasra. Edisi Ketiga. Yogyakarta: BPFE.

[7] Tarigan, Henry Guntur. 1984. Prinsip-Prinsip Dasar Sastra. Bandung :Angkasa.

[8] Waluyo, Herman J. 2005. Apresiasi Puisi. Jakarta :Gramedia Pustaka Utama.

[9] Maolani, Ilham. 2007. Metode Pembelajaran. Dalamhttp://ilhammaolani.blogspot.com/2018/0 8/metode -pembelajara. Html., diakses pada 29 Agustus 2018.

[10] Sudjana, Nana. 2008. Penilaian Hasil Proses Belajar Mengajar. Bandung :Rosdakarya.

[11] Pusat Kurikulum Badan Penelitian dan Pengembangan Departemen Pendidikan Nasional.2006.Model Penilaian Kelas KurikulumTingkat Satuan Pendidikan SMP/MTS. Badan Penelitian dan Pengembangan KTSP:Depdiknas.

[12] Pradopo, Rachmat Djoko. 2009. Pengkajian Puisi. Cetakan XI. Yogyakarta : Gajah Mada University Press.

[13] Roestiyah, NK. 2008. Strategi Beajar Mengajar. Cetakan VII. Jakarta: Rineka Cipta.

[14] Suwandi, Sarwiji.2005. Bahasa dan Notasi dalam Karya Tulis Ilmiah. Materi Perkuliahan Mata Kuliah Menulis Ilmiah. Surakarta : UNS Press.

[15] Sukirno.2010. Belajar Cepat Menulis Kreatif Berbasis Kuantum. Yogyakarta: Pustaka Pelajar.

[16] Sayuti, A Suminto. 2002. Berkenalan dengan Puisi. Yogyakarta: Gama Media

[17] Sagala, Syaiful.2006. Konsep dan Makna Pembelajaran. Bandung :Alfabet. 